\title{
ROLE OF MARITAL CONFLICT AND SPECIFIC ASPECTS OF PARENTING IN PREDICTING ADOLESCENT'S PSYCHOLOGICAL ADJUSTMENT OF SPANISH ADOLESCENTS ${ }^{1}$
}

\author{
Olga Vlachynská2, María del Mar González ${ }^{3}$, Ana López Jimenez ${ }^{3}$, \\ Lenka Lacinová ${ }^{2}$ \& Stanislav Ježek ${ }^{2}$
}

Abstract

The aim of this study was to examine the family process model of adolescent psychological adjustment in a sample of 12 to 18 year-old 456 Spanish adolescents $(\mathrm{M}=14.61$; $\mathrm{SD}=0.53$; $56 \%$ of females). The self-report scales administered to the adolescents included a short version of Children's Perception of Interparental Conflict Scale, six subscales of Youth Self Report, and two subscales of Child's Reports of Parental Behavior Inventory. Structural equation modeling (SEM) was used to examine the family-system-theory based model. This model suggested that 1) adolescent perception of marital conflict affects adolescent psychological adjustment; 2) this association can be explained by adolescent perception of parental hostility and harsh punishment by both parents, and 3) the negative association can be buffered by adolescent perception of parental support and open communication. The results show that parental hostility and harsh punishment by both parents partially mediated the association between marital conflict and adolescent internalizing and externalizing behaviors in a simple mediation model. Next, parental support and open communication partially buffered the relation between marital conflict and adolescent internalizing and externalizing behaviors in a simple mediation model. However, using a complex model of structural equation modeling we did not find support for the model where parenting mediates the relationship between marital conflict and adolescent adjustment. Our findings do not support the usual direction of the spillover hypothesis but indicate that parenting is linked to marital conflict and both of them play an important role in adolescent adjustment.

Key words: adolescent, marital conflict, parenting, psychological adjustment, spillover hypothesis

Received: 10. 1.2017

Approved: 18.9. 2017

\footnotetext{
${ }^{1}$ This study was partially supported by GAČR (project GA16-03059S).

${ }^{2}$ Institute for Research on Children Youth and Families, Masaryk University, Brno

${ }^{3}$ Universidad de Sevilla
} 


\section{Introduction}

The first generation of researchers found a direct link between marital conflict and psychological adjustment of children and youths (Buehler, et al., 1997). First, the existence of the direct connection between overall marital discord or divorce and child functioning was established (Jouriles, et al., 1991), then marital conflict was identified as the most important aspect of marital discord related to children and youths' maladjustment (Buehler, et al., 1997), and ultimately it was found that a child's exposure to overt conflict and his perception of the meaning of the conflict play an essential role for understanding this dynamic (Cantón, Cortés, \& Justicia, 2007; Fincham, 1994). Buehler and colleagues (1997) examined 68 studies relating to marital conflict and psychological adjustment of children and youths and found a moderate/weak effect size. This weak effect size can be explained by the existence of many variables that moderate or mediate the link and other extra familiar factor variables that influence youth's and child's maladjustment.

The second generation of research in recent years has focused on identifying mechanisms and processes which explain the link between marital conflict and youth's and child's maladjustment (Cox, Brooks, \& Gunn, 1999; Fincham, 1994). It is supposed that conflict is an inevitable part of close relations and that it can play a positive role, such as promoting change, externalizing emotions and motivating persons to relate to their significant others (Redorta, 2007). Constructive marital disagreement may be benign (Davies, Myers, Cummings, \& Handel, 1990) or even beneficial for children if parents serve as an adaptive model of problem-solving skills (Cummings \& Wilson, 1999). However, couples differ considerably in intensity, frequency and in strategies for conflict resolution (Goeke-Morey, Cummings, \& Pabb, 2007). Depending on the conflict characteristics both constructive and destructive effects on the marital couple, children and the whole family can be found (Cummings \& Davies, 2010).

A cognitive contextual framework (Grych \& Fincham, 1990) emphasizes cognitive aspects of the child's appraisal and evaluation of marital conflict. Marital conflict is conceptualized as a stressor that leads to an attempt by the child to understand the conflict and cope with it (Grych \& Fincham, 1990). This model proposes two stages of appraisal: (1) through primary processing the child estimates the degree of potential threat. If the child perceives the conflict as threatening, relevant and negative, in the second stage (2) the child will draw inferences about why the conflict happened, who is responsible, and whether he has the resources to cope with it. Children would feel worse if they attributed the cause to themselves, or to some stable and global aspect (Cantón, Cortés, \& Justicia, 2007; Gerard, et al., 2005). A high level of arousal provoked by an aggressive and hostile conflict can disorganize the cognitive process and leads to distorted interpretation. However, a child's cognition is also influenced by other contextual factors, such as their previous experience with conflicts within the family and relations between family members (Grych, et al., 2000).

The family system theory suggests that individual members are part of an interdependent, complex and hierarchically organized whole - a family (Minuchin, 2001). Conflict that originates in one of the parts is likely to extend to other parts of the family system because boundaries between subsystems are permeable and all the family dynamics have a reciprocal and circular character (Cox \& Paley, 1997). The central model of this framework has been the spillover effect (Benson, Buehler, \& Gerard, 2008; Buehler, Benson, \& Gerard, 2006; Gerard, Krishnakumar, \& Buehler, 2006; Krishnakumar, Buehler, \& Barber, 2003). The spillover 
effect is a transfer of emotions, mood or behavior through family subsystems (Cox \& Paley, 1997) and it serves as an explanative framework of how marital conflict affects other family relations. Parenting compromised by conflict has received the greatest amount of attention (Erel \& Burman, 1995; Krishnakumar, \& Buehler, 2000). While sound marital relations promote positive affect that allows parents to employ optimal educational strategies; frustration and anger created by hostile marital interactions are related to dysfunctional interactions between parents and children (Krishnakumar \& Buehler, 2000).

Some studies have found that disturbed parenting by both mothers and fathers completely mediated the relations between marital hostility and externalizing and internalizing problem behaviors of adolescents (Buehler, Benson, \& Gerard, 2006) and children (Kaczynski et al., 2006), while others found only a partial mediation effect (Krishnakumar, Buehler, \& Barber, 2003). A meta-analysis of 39 studies with an effect size $d=0.62$ found a generally negative relationship between marital conflict and parenting behaviors (Krishnakumar \& Buehler, 2000). Results indicate that marital conflict is prejudicial for the vast majority of parental functioning and the strongest impact is felt in the areas of harsh discipline and acceptance. The association is stronger, when interparental hostility is examined instead of the multidimensional construct of marital conflict (Krishnakumar \& Buehler, 2000). Results of investigations that studied which aspects of parenting were linked to marital conflict, and which dimensions of marital conflict play a central role in these relationships usually found analogous results (Benson, Buehler, \& Gerard, 2008; Buehler, Benson, \& Gerard, 2006; Erath et al., 2006; Rhoades, 2011). It seems that hostility is a central dimension of marital conflict that relates strongly to various aspects of parenting, for example inconsistency, intrusiveness, low level of acceptance, low level of control (Buehler, Benson, \& Gerard, 2006) and low level of emotional availability (Sturge-Apple, Davies, \& Cummings, 2006). However, the strongest connection is found between marital hostility and harsh discipline (Buehler, Benson, \& Gerard, 2006), which also appears to be the strongest mediator between marital conflict and the psychological adjustment of children and youths (Erath et al., 2006; Benson, Buehler, \& Gerard, 2008; Gerard, Krishnakumar, \& Buehler, 2006; Rhoades, 2011).

However, positive parenting may subdue the negative effect of marital conflict on youths and children. Grych and Fincham (1990) postulated that children with positive relations with their parents perceive marital hostility as less threatening. The relationship between positive parenting, marital conflict and psychological maladjustment of youths and children has not been studied very extensively. In a meta-analysis by Erel and Burman (1995), good childparent relations mitigate the negative impact of marital conflict on the psychological adjustment of the child. Lindhal and Malik (2011) found that family cohesion moderated the relation between self-blame and marital conflict. Low involvement and supervision, and low self-disclosure of adolescents significantly moderate the relation between marital hostility and adolescent psychological adjustment (Buehler, Benson, \& Gerard, 2007) while low level of parental acceptance was the most significant mediator between marital conflict and internalizing behavior problems (Benson, Buehler, \& Gerard, 2008).

Even though the spillover effect seems to have a major explicative potential (Krishnakumar \& Buehler, 2000), there are other theories which can serve as alternative or complementary models to understand the dynamics of the relation between marital conflict and disturbed parenting. Social learning theory is consistent with the spillover hypothesis in the prediction that marital conflict is linked to parenting (Erel \& Burman, 1995). However, the social 
learning theory suggests that the correlation between the level of marital conflict and inappropriate parenting strategies is due to the lack of interpersonal skills of parents, while the spillover hypothesis suggests that marital conflict predicts disturbance of parental functions and that there is a causal relation between them (Krishnakumar \& Buehler, 2000).

The social learning theory (Bandura, 1987) postulates that children learn dysfunctional behavior patterns by observing their parents' behaviors. In families with a high level of hostile marital conflicts, boys may imitate the aggressive behavior of their fathers while girls may imitate the sadness and the tension of their mothers (Camara \& Resnick, 1988). Lack of parents' basic interpersonal skills negatively impacts both marital and parent-child relations (Kazcynski et. al., 2006; Krishnakumar \& Buehler, 2000).

An additional explanation can be derived from the role strain theory which suggests that marital problems or problems in parent-child relations are stress factors that may lead to additional problems (Erel \& Burman, 1995). While individual differences are amplified under stress (Caspi \& Moffitt, 1993) and marital conflict can be a source of pervasive, long-term, daily stress, parental personality characteristics in a highly conflictive marriage may be strongly related to parenting practice.

Most investigations on marital conflict and the psychological adjustment of children has taken place in English speaking countries. However, some research has been done in Spain (e.g., Sanz, Iraurgi, Marínez - Pampliega, \& Cosgaya, 2007; Ochoa, Ferrer, \& Pérez, 2006; Iraurgi, Martínez - Pampliega, Iriarte, \& Sanz, 2011; Morgado, 2008). We were only able to find one investigation which measured the indirect impact of marital conflict through parental functioning (Ochoa, Ferrer, \& Pérez, 2006).

The aim of this study is to examine the nature of the relationship between marital conflicts, various components of parent functioning and psychological adjustment of Spanish adolescents. It seems that this dynamic is a widespread pattern and can be found in different cultural frames (Krishnakumar, Buehler, \& Barber, 2003), so we expect (H1) that the direct relation between marital conflict and psychological maladjustment of adolescents will be positive and significant as well as (H2) the relation between marital conflict and parenting functioning. Drawing on the spillover hypothesis, (H3) we suppose that the parental functioning of both parents will mediate the relation between marital conflict and psychological adjustment of adolescents. We introduced harsh discipline of both parents as an important part of latent variable parental functioning, coupled with communication and perceived support. While mixed results appear when the child's gender comes into focus in the context of marital conflict (Davies \& Lindsay, 2001), we controlled for possible differences between boys and girls in the strength and nature of the relationship between marital conflicts, parenting and adolescent adjustment, without designing any clear hypothesis.

\section{Method}

\section{Sampling Procedures and Characteristics}

The sample studied comprised 338 adolescents who reported living with their married parents, from three independent Secondary Grammar Schools (76\%) or on their first courses of College from the region of Seville. 96 adolescents who reported having divorced parents were 
not included in this sample. The age of the participants ranged from 12 to $18(\mathrm{M}=14.61$; $\mathrm{S}=0.53$ ). $54 \%$ of participants were female and $46 \%$ were male. Their educational background was similar to that of the community from which they were drawn. $49 \%$ reported having a mother with incomplete or complete elementary school education, $16 \%$ secondary education, $13 \%$ non-university higher education and $23 \%$ university education.

All the constructs were based on youth perception and were assessed using school administered pencil-and-paper questionnaires. The data were collected in June 2011. A trained investigator was present in class to explain the topic of the study, motivate students to fill in the survey and answer all questions. Students had all the time they needed to complete the survey. After all the participants had finished, a short debriefing took place. Students were left with the researcher's email.

\section{Measures}

Marital conflict. The adolescents completed a Spanish short version of Children's Perception of Interparental Conflict (CPIC; Grych, Seid, \& Fincham, 1992) adapted by Oliva et al. (2011) which is composed of 13 items on three subscales (triangulation, frequency and intensity), such as: "When my parents disagree one of them (or both) gets madder and madder". The scale is designed to evaluate the adolescent's or child's perceptions of marital conflict between their parents and is widely used in studies in the same field. The adolescents responded to questions on a 7 point Likert scale $(1=$ totally not true, $7=$ totally true $)$. The internal consistency of the scale was acceptable $(\alpha=0.89)$.

Psychological adjustment of adolescents. The adolescents completed six subscales of Youth Self Report (Achenbach \& Rescorla, 1991), adapted to a Spanish population by Lemos, Fidalgo, Calvo, and Menéndez (1992), including anxious/depressed behavior, withdrawn behavior, somatic complaints, aggressive behavior and delinquent behavior. YSR is extensively used and has excellent psychometric properties for the measurement of both externalizing and internalizing problem behaviors. The responses' format ranges from 0 (not true) to 2 (very true) with questions such as: "I try to get a lot of attention" and "I feel worthless or inferior". Internal consistency of the scale was acceptable analyzed both as a whole $(\alpha=0.93)$, or divided into externalizing problem behaviors $(\alpha=0.91)$ and internalizing problem behaviors $(\alpha=0.75)$.

Parental Functioning. The adolescents completed two subscales of Child's Reports of Parental Behavior Inventory (Schaefer, 1965) through its adaptation to a Spanish population (Samper, Cortés, Mestre, Nácher, \& Tur, 2006). The participants rated each item on a three point scale $(1=$ not true, $2=$ somewhat true, $3=$ very true $)$. The original version has been extensively used in research in the same field (see Safford, Alloy, \& Pierraci, 2007). A subscale called "Negative subscale" composed of 16 items, such as: "He/she always lets me know when I break some rule" or "He/she wants to control everything" was used to measure perceived hostility and severe discipline. The internal consistency of the subscale was acceptable both for mothers $(\alpha=0.85)$ and fathers $(\alpha=0.87)$. Parenting support is reflected in behaviors such as helping with everyday problems, praising the children's accomplishments and showing affection (Amato \& Fowler, 2002). The subscale called "Support and decision making stimulation", composed of 13 items such as: "He/she often mentions that I'm doing 
well" or "He/she likes to speak with me", was employed to measure open communication and perceived support. The internal consistency of the subscale was acceptable both for mothers $(\alpha=0.85)$ and fathers $(\alpha=0.90)$.

Background variables. Information about the adolescents' gender, age, course participation, name of the school he/she attended and education of his/her mother and father were collected.

\section{Date analysis and results}

The intercorrelations, means and standard deviations are reported in Table 1. Girls $(\mathrm{N}=180$, $\mathrm{M}=15.26, \mathrm{SD}=9.57 ; \mathrm{p}<0.01)$ reported significantly more internalizing problem behavior than boys $(\mathrm{N}=158 ; \mathrm{M}=11.77 ; \mathrm{SD}=8.54 ; \mathrm{p}<0.01)$ and they scored significantly higher on perceived marital conflict between their parents $(\mathrm{N}=180, \mathrm{M}=46.18 ; \mathrm{SD}=16.8 ; \mathrm{p}<0.05)$ than boys $(\mathrm{N}=158, \mathrm{M}=42.00, \mathrm{SD}=14.12 ; \mathrm{p}<0.05)$. Boys reported having significantly more open communication and perceiving more support from their fathers $(\mathrm{N}=158, \mathrm{M}=$ 30.04; $\mathrm{S}=6.05 ; \mathrm{p}<0.05)$ than girls $(\mathrm{N}=180, \mathrm{M}=28.00 ; \mathrm{SD}=6.35 ; \mathrm{p}<0.05)$. Structural equation modeling (SEM) was employed to test the study hypothesis. The maximum likelihood estimation method, implemented through Mplus 6.0 computer software (Muthen \& Muthen, 2007) was used to estimate all models.

Tab 1 Descriptive Statistics and Bivariate Intercorrelations between the Measures

\begin{tabular}{|c|c|c|c|c|c|c|c|}
\hline Variables & 1 & 2 & 3 & 4 & 5 & 6 & 7 \\
\hline 1. Marital Conflict & 1 &, $32(* *)$ &,$- 42(* *)$ &, $30(* *)$ &,$- 36(* *)$ &, $31(* *)$ &, $38(* *)$ \\
\hline 2. Fathers' Hardiness &, $32(* *)$ & 1 &,$- 36(* *)$ &, $60(* *)$ &,$- 29(* *)$ &, $39(* *)$ &, $37(* *)$ \\
\hline 3. Fathers' Support and Open Communication &,$- 40(* *)$ &,$- 36(* *)$ & 1 &,$- 17(* *)$ &, $45(* *)$ &,$- 24(* *)$ &,$- 23(* *)$ \\
\hline 4. Mothers' Hardiness &, $30(* *)$ &, $60(* *)$ &,$- 17(* *)$ & 1 &,$- 46(* *)$ &, $44(* *)$ &, $36(* *)$ \\
\hline 5. Mothers' Support and Open Communication &,$- 36(* *)$ &,$- 29(* *)$ &, $45(* *)$ &,$- 46(* *)$ & 1 &,$- 38(* *)$ &,$- 33(* *)$ \\
\hline 6. Externalizing Problem Behavior &, $31(* *)$ &, $39(* *)$ &,$- 24(* *)$ &, $44(* *)$ &,$- 38(* *)$ & 1 &, $56(* *)$ \\
\hline 7. Internalizing Problem Behavior &, $38(* *)$ &, $37(* *)$ &,$- 23(* *)$ &, $36(* *)$ &,$- 33(* *)$ &, $56(* *)$ & 1 \\
\hline \multirow[t]{2}{*}{ Mean (boy girls) } & 35,20 & 25,82 & 30,02 & 27,17 & 29,93 & 11,10 & 11,94 \\
\hline & 39,83 & 25,88 & 28,04 & 26,43 & 30,16 & 11,90 & 15,54 \\
\hline \multirow[t]{2}{*}{ SD (boy girls) } & 14,00 & 6,83 & 5,85 & 6,61 & 5,22 & 10,78 & 8,43 \\
\hline & 16,82 & 6,69 & 6,65 & 6,08 & 5,28 & 8,18 & 9,11 \\
\hline
\end{tabular}

** Coefficients are significant on 0,01 (bilateral)

As a first step, it was necessary to establish the direct association between marital conflicts, aspects of parenting of both parents and both externalizing and internalizing problem behavior (see Table 1). All the direct paths were significant, so the first criterion was established and the first hypothesis was confirmed. As a next step, parenting variables of both parents were included in the model (see Figure 1 for externalizing problem behavior and Figure 2 
internalizing problem behavior) as four latent constructs of "parenting", while marital conflict and children's adjustment were included as manifested constructs. The Comparative Fit Index (CFI), the Root Mean Square Error of Approximation (RMSEA) and the Standardized Root Mean Square Residual (SRMR) were used to assess the fit of the model. When the full model was estimated (Figure 1), the model fit was adequate both for internalizing problem behavior $\left[\chi^{2}(\mathrm{~N}=338)=41.80 ; \mathrm{df}=17 ; \mathrm{p}=0.00 \mathrm{CFI}=0.96 ; \mathrm{RMSEA}=0.08 ; \mathrm{SRMR}=0.06\right]$ and for externalizing problem behavior $\left[\chi^{2}(\mathrm{~N}=338)=34.13\right.$; $\mathrm{df}=14 ; \mathrm{p}=0.002 ; \mathrm{CFI}=0.96$; RMSEA $=0.09 ;$ SRMR $=0.07]$. Values of the RMSEA and SRMR below 0.10 indicate an adequate fit (Byrne 1998; Diamantopoulos \& Siguaw 2000; Kelloway 1998) and for the CFI, values between 0.90 and 1.0 indicate an adequate fit (Muthén \& Muthén 2010).

In order to test for mediation effects (Baron \& Kenny 1986; MacKinnon et al., 2002), the standardized total effects and total indirect effects were calculated using the Model Indirect command in Mplus. The total indirect effects of a marital conflict on internalizing (see Fig. 1) and externalizing (see Fig. 2) problem behavior in the child are the mediated effects via parental functioning that is depicted separately in the model for males $(\mathrm{M})$ and females $(\mathrm{F})$. When the latent construct of parental functioning was introduced into the model, the strength of direct association between marital conflict and both externalizing and internalizing problem behavior was reduced to under statistical significance. These results indicate that parental functioning completely mediated the relation between marital conflict and adolescent adjustment both for boys and girls (see Fig. 1 and Fig. 2).

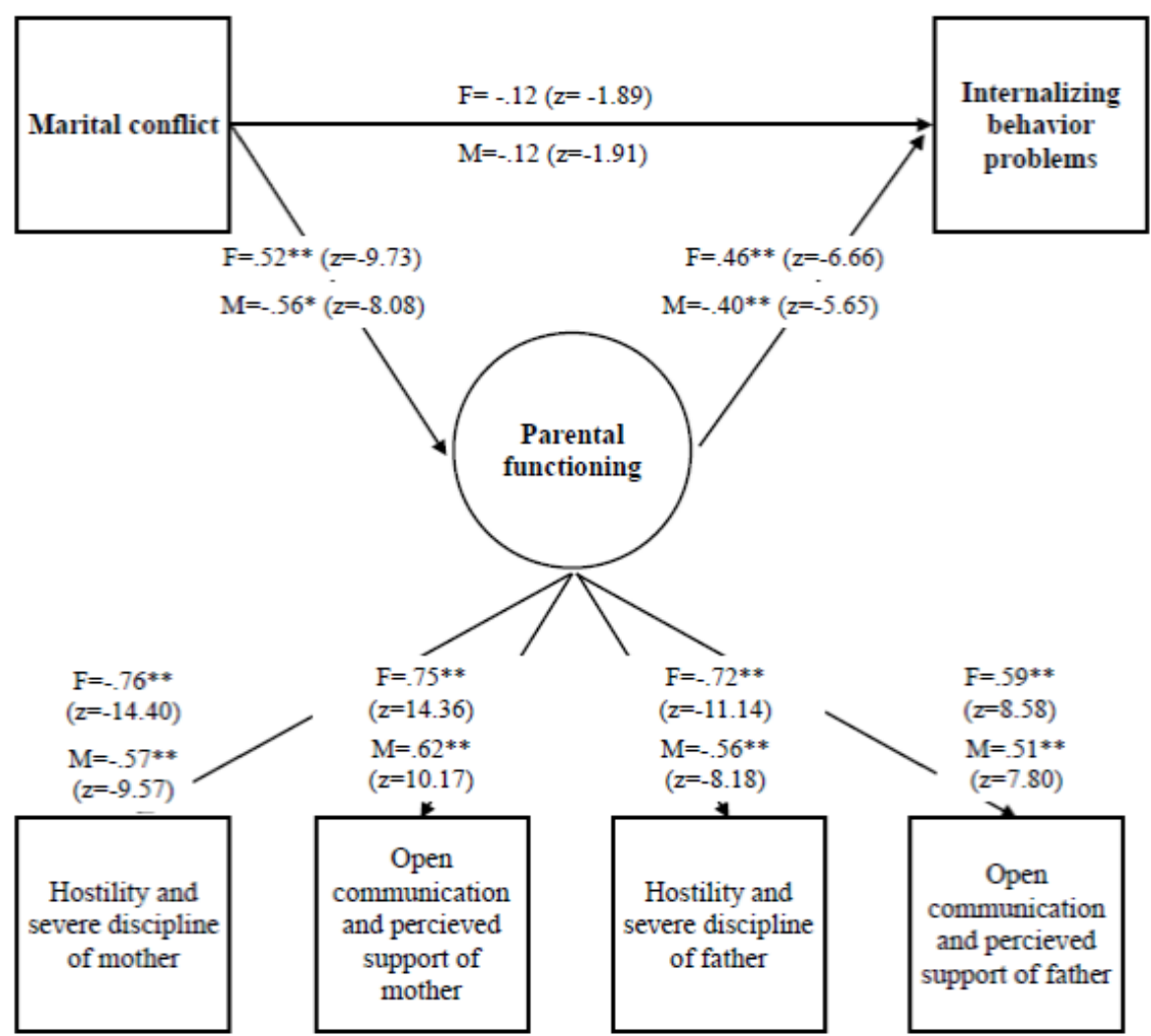

Fig. 1 The predictors of internalizing behavior problems. Note: ${ }^{* *} p<0.01 ;{ }^{*} p<0.05$, F females; M males $\mathrm{CFI}=0.96 ; \mathrm{RMSEA}=0.08 ; \mathrm{SRMR}=0.06$ 


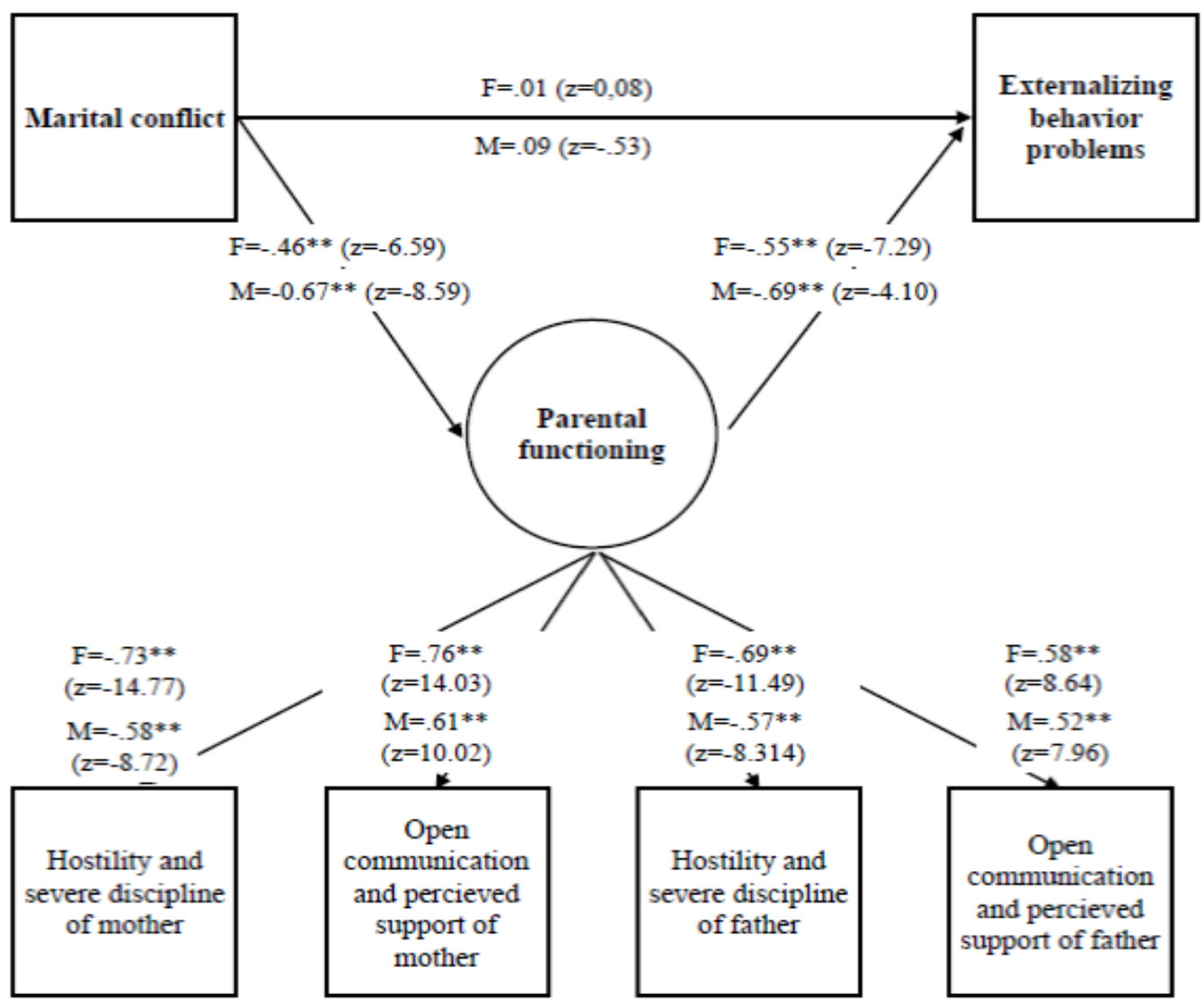

Fig. 2 The predictors of externalizing behavior problems. Note: ${ }^{* *} p<0.01 ;{ }^{*} p<0.05$, F females; M males $\mathrm{CFI}=0.96 ; \mathrm{RMSEA}=0.09 ; \mathrm{SRMR}=0.07$

Finally, we tested to see if there were any differences between models for boys and girls, separately for externalizing and internalizing problem behavior. This was done by using the chi-square test for the difference between two nested models: a model with "invariance between boys and girls assumed (M1)" and a model with "no invariance between boys and girls assumed (M2)". The invariance of parameters being tested is confirmed when the chisquare difference is not statistically significant (Dimitrov, 2006).

For internalizing problem behavior the chi-square difference between models was not statistically significant, indicating no major difference between the pathways in the model for boys and girls (Table 2). For externalizing problem behavior the chi-square difference between models was statistically significant (Table 3), so we decided to conduct an additional analysis in order to determine the pathways in which the model could differ for boys and girls. 
Table 2

Test for the invariance between the models of boys and girls for internalizing problem behavior.

\begin{tabular}{lllll}
\hline Model & $\chi^{2}$ & $d f$ & $\Delta \chi^{2}$ & $\Delta d f$ \\
M1 & 41.796 & 17 & & \\
M2 & 32.439 & 14 & $9257(\mathrm{p}<0.01)$ & 3
\end{tabular}

M1: Model with invariance between boys and girls assumed

M2: Model with no invariance between boys and girls assumed
Table 3

Test for the invariance between the models of boys and girls for externalizing problem behavior.

\begin{tabular}{lllll}
\hline Model & $\chi^{2}$ & df & $\Delta \chi^{2}$ & $\Delta$ df \\
M1 & 45.715 & 17 & & \\
M2 & 34,127 & 14 & $11,588(\mathrm{p}>0.01)$ & 3 \\
M3 & 37,5 & 16 & $8,215(\mathrm{p}<0.01)$ & 1
\end{tabular}

M1: Model with invariance between boys and girls assumed M2: Model with no invariance between boys and girls assumed

MB: all pathways were assumed as invariant, excepting the pathway between marital conflict and parental functioning

The chi-square difference was not statistically significant (Table 3) when conducted between the model "invariance between boys and girls assumed (M1)" and the model in which all pathways were assumed as invariant, excepting the pathway between marital conflict and parental functioning (M3). These results indicate that the difference between models based on boys and girls is placed on the pathway from marital conflict to parental functioning.

\section{Discussion}

The present study was designed to evaluate the nature of pathways between marital conflict, the specific form of maternal and paternal parenting and psychological adjustment among Spanish adolescents.

The findings of this study confirmed a direct link between marital conflict and the psychological adjustment of adolescents. The strength of this association was similar both for internalizing and externalizing problem behaviors. This relation had been previously confirmed on a Spanish population (e.g., Cosgaya et al., 2008; Iraurgi et al., 2011; Morgado, 2008). Various studies revealed that hostile and overt marital conflict is highly stressful for children and youths (e.g., Cummings et al., 2002; Davies et al., 1999; Goeke-Morey et al., 2003). When children perceive marital conflict as threatening, negative and self-relevant, they respond with major stress (Gerard et al., 2005) because they are sensitive to its broader implications on family system stability (Goeke-Morey et al., 2007). Destructive marital conflict tactics, such as physical aggression toward a spouse or objects, threat to intactness, verbal and nonverbal hostility all elicit negative reactions and distress in children (GoekeMorey et al., 2003). A history of repeated exposure to destructive marital conflicts fosters greater expectancies of hostility in a current conflict, engenders children's negative reactions and motivates the child to reduce emotional arousal through avoidance or intervention in a conflict (Davies et al., 1999). The tendency to blame oneself (Ablow et al., 2009) and the fear that the parents will include him in their disputes (Atkinson, Dadd, \& Chipuer, 2008) make 
the child or youth vulnerable to developing internal problem behavior, while aggressive parents' behaviors may be internalized and prompt the child or youth to display external problem behavior (Cabrera, Guavera, \& Barrera, 2006). Children and youths who develop external problem behavior may then contribute to the maintenance of negative family processes (Gerard, Krishnakumar, \& Buehler, 2006).

It was confirmed that marital conflict was linked to a high level of harsh parenting by both parents and a low level of open communication and perceived support by both parents. These findings have various explanations: (1) Parents with a high level of marital conflict may lack energy and motivation to interact effectively with their children and protect them from the intense negativity. Theoretically, marital conflict emerges from increased irascibility and reduces parents' threshold of tolerance to child's disruptive behaviors. Parents may be less supportive, less empathic, and less consistent and employ harsher coercive methods (Kazcynski et al., 2006; Krishnakumar \& Buehler, 2000). This explication is congruent with the spillover hypothesis, one of the most prominent explications of the relation between marital conflict and disturbed parenting. (2) Parents may also deny their marital conflict by focusing on the child's real or imagined problems. They may create, maintain or exacerbate child's real or imagined problem behavior and construct artificial solidarity in the marital relationship (Cox \& Paley, 1997). (3) Another explication can be drawn from the role strain theory. Stress created in one relationship or one area of life may lead to problems in other areas, which produces additional stress (Erel \& Burman, 1995). (4) Alternatively, some parents may be ineffective in managing their disagreements because of their lack of problemsolving and interpersonal skills. Social learning theory postulates that this deficiency impacts negatively on both marital and parent-child relations (Kazcynski et al., 2006; Krishnakumar, \& Buehler, 2000).

Other explications for the current findings can be derived from the social learning theory (Bandura, 1987) which supposes that people usually display the same interpersonal style in all their relations. Poor communicative skills and a high level of hostility affect interactions both with children and spouse. The lack of empathy and low sensibility to the needs of other people may provoke marital conflicts and make it difficult to manage them constructively, while an aggressive attitude may trigger a pattern of hostile interactions in the whole family. Abidin (1995, in Cabrera, Guevara, \& Barrera, 2006) found that the personal resources of a parent play a central role in the development of parenting behavior under stress. However, most family scholars assume that children and parents influence one another in a reciprocal fashion (Koenig, Barry, \& Kochanska, 2010). According to Belsky (1984, in Bogenscheider, Small, \& Tsay, 2011) the parent-child relation depends on three basic components: the parent's characteristic, the child's characteristic and contextual sources of support, such as the marital relationship. The parent's characteristic is considered to be the most important factor, while contextual sources of support the least influential. Haan, Dekovic, and Prinzie (2011) found that whereas the parent's own personality was more relevant than the adolescent personality for the explication of harsh parenting, both adolescent personality and parental personality warmth were similarly important in predicting warmth. Other studies have suggested that children actively participate in the maintenance of destructive family interactions. In a longitudinal study, Gerard et al. (2006) found a relation between prior externalizing problem behaviors of children and subsequent parent-child conflict. Contrary to Belsky's prediction (Belsky, 1984), Bogeschneider, Small and Tsay (1997) found that 
children's characteristics actually assume more importance during adolescence than parents' characteristics in predicting parenting practice. Shermerhorn et al. (2007) found that proactive behavior of children subdues marital conflict, while disregulated behavior was linked to a higher level of hostile marital interactions. Nicolotti, El-Sheikh and Whitson (2003) found that children's proactive coping style and their seeking for social support acted as a protective factor between marital conflict and children's maladjustment.

When the full model, with various aspects of parenting as mediators of the relation between marital conflict and psychological adjustment of the adolescent, was estimated surprisingly it did not fit as well as it had in the vast majority of previous investigations (for example, Kaczynski, Lindhal, Malik, \& Laurenceau, 2006; Krishnakumar, Buehler, \& Barber, 2003; Krishnakumar, \& Buehler, 2000; Low, \& Stocker, 2005, Rhodes, Leve, Neiderhiser; SturgeApple, Davies, \& Cummings, 2006). Current findings may be limited by the method employed and the statistical models. The same scale of "Child's Reports of Parental Behavior Inventory" (CRPBI) was used to measure four different variables, so results of the first structural model, where various aspects of parenting appear as mediators between marital conflict and adolescent psychological adjustment, may be skewed due to the effect of multicollinearity. Although the scale "Child's Reports of Parental Behavior Inventory" (CRPBI) is extensively used in Anglo-Saxon countries, subscales that measured variables of the current study were drawn from its adaptation to a Spanish population (Samper, Cortés, Mestre, Nácher, \& Tur, 2006) which had never been used in a similar investigation. A similar situation may occur with the short version of "Children's Perception of Interparental Conflict" (CPIC; Grych, Seid, \& Fincham, 1992) adapted by Oliva et al. (2011).

Alternatively, the developmental stage of the sample studied may play an important role in explaining the results. Parents' personality traits may be especially important during adolescence when rapid physical, cognitive and psychological changes trigger the parent child-relationship and its necessary transformation from a complementary relationship based on inequality and unilateral authority, to a reciprocal relation based on cooperation and negotiation (Macek, 2003). Adolescents' developed cognitive capacity prompts them to judge differences between the proclaimed values and actual behavior of their parents (Matějček, 2005). For parents, it may be stressful to cope with new educational challenges. Both mothers and fathers of adolescents report higher levels of stress and lower levels of life satisfaction than parents of younger or older children (Silverberg \& Steinberg, 1990), adolescent children are also the most frequent source of marital disagreement during the midlife of parents (Thurnher, 1976). Parents who built on an authoritarian parenting style and maintained restrictive control may clash with a disobedient youngster who refuses to respond to restrictive, punitive parenting practices. Haan, Dekovic, and Prinzie (2011) found that parent personality was especially important in predicting harsh discipline toward the adolescent. High levels of stress together with difficulties in parent-child interactions may increase the level of parents' authoritarian behaviors which then lead to destructive conflict between adolescent and parent, and compromise their relationship (Abidin, 1995, in Cabrera, Guevara, \& Barrera, 2006). The role strain theory proposes that this dynamic may affect marital relations and increase the level of marital conflict (Erel \& Burman, 1995). 


\section{Limitations and recommendations}

Several methodological limitations warrant caution in the interpretation of results.

Firstly, the character of the sample should be taken into account when generalizing. The data were gathered from a sample from an urban area of Seville with a higher proportion of adolescents from families with a lower socio-economic level than the national average. According to Bronfenbrenner's ecological theory (Brofenbrenner, 1979), family processes and contextual factors, such as the parents' social class or race often interact in affecting children's development, consequently we suggest caution when generalizing the current results to a larger population.

All variables were gathered through the questionnaire survey which was based on youth perception. Various studies suggest that adolescents are good informants of their behavior and the behavior of other people (Askers, Massey, Clarke, \& Lauer, 1983). Their reports of optimum parenting practice are congruent with parents' perceptions of parenting competence (Bogenschneider, Small, \& Tsay). However, they tend to perceive family functioning more critically than their parents do (Bagley, Bertrand, Bolitho, \& Mallick, 2001). It has been noted that higher correlations between marital conflict and a child's maladjustment are found if children estimate the level of marital conflict compared to studies using other types of methodology (Fincham, 1994). The use of self-reporting measures or other indices of individual perception may be problematic when they are interpreted as reflecting properties of a larger system (Cox \& Paley, 1997). Adolescents are active agents and participants in the family dynamic, so their perceptions tend to be skewed by their experience and personalities. Siblings in one family evaluate the marital conflict of their parents differently (Richmond, \& Stocker, 2003) and usually tend to perceive the parenting practices of their parents differently as well (Daniels \& Plomin, 1985). Conceptual models about marital conflict and its influence on a child's psychological functioning, such as the cognitive-contextual framework or the emotional security theory postulate that internal representations about family relationships of children and youths are the central risk mechanism (Sturge-Apple et al., 2006). A survey can be a valid way how to know them. As with any other method used in psychology, a questionnaire survey provides valuable complementary information/when evaluated in the larger context of important findings from field research (Davies et. al., 1999). Compared to experimental methods or those that gather information from various members of the family, a survey is an accessible method that offers the possibility of obtaining data from a larger sample. However, no single methodology will answer the many questions that remain concerning the processes linking marital relations and child development. Progress toward process-oriented explanation requires the use of multiple methodologies (Cummings \& Davies, 2002).

With these limitations in mind, current results should be understood as exploratory rather than confirmatory, encouraging further investigations in different countries and cultures. We suggest: (1) the use of a wide range of methodologies, such as observation or experiment, which directly access family interactions; (2) a longitudinal design to study the development of family dynamics, and; (3) the gathering of data from various family members to study convergences and divergences between the individual perceptions of family members; (4) to study family dynamics using various conceptual models which facilitate the understanding of complex family processes from different perspectives. 
As well, for those professionals who work with adolescent clients, we highly recommend to have in perspective the whole family system and its impact, when treating any of the externalizing or internalizing problem behaviors of their clients.

\section{Literature}

Ablow, J. C., Measelle, J. R., Cowan, P. A., \& Cowan, C. P. (2009). Linking Marital Conflict and Children's Adjustment: The Role of Young Children's Perceptions. Journal of Family Psychology, 23 (4), 485-499.

Achenbach, T.M. (1991). Manual for the Youth Self Report and 1991 profile. Burlington, VT: University of Vermont.

Askers, R. L., Massey, J., Clarke W., \& Lauer, R.T. (1983). Are Self-Reports of Adolescent Smoking Valid? Biochemical Measures, Randomized Response, and the Bogus Pipeline in Smoking Behavior. Social Force, 62, 234-251.

Atkinson, E. R., Dadds, M. R., \& Chipuer, H. (2009). Threat is a Multidimensional Construct: Exploring the Role of Children's Threat Appraisals in the Relationship Between Interparental Conflict and Child Adjustment. Journal of Abnormal Child Psychology, 37, 281-293.

Bandura, A. (María Zaplana, trad.) (1987). Pensamiento y acción: Fundamentos sociales. Barcelona, Spain.

Baron, R. M. \& Kenny, D. A. (1986). The Moderator-Mediator Variable Distinction in Social Psychological Research: Conceptual, Strategic, and Statistical Considerations. Journal of Personality and Social Psychology, 51(6), 1173-1182.

Benson, M. J., Buehler, Ch., \& Gerard, J. M. (2008). Interparental Hostility and Early Adolescent Problem Behavior: Spillover via Maternal Acceptance, Harshness, Inconsistency, and Intrusiveness. The Journal of Early Adolescence, 28(3), 428-454.

Bogenschneider, K., Small, S. A., \& Tsay J. C. (2011). Child, Parent and Contextual Influences on Perceived Parenting Competence among Parents of Adolescents. Journal of Marriage and Family, 59(2), 345-362.

Brody, G. H., Pillegriny, A. D., \& Rigel, I. E. (1986). Marital Quality and Mother-Child and Father-Child Interactions with School-Aged Children. Developmental Psychology, 22(3), 291-296.

Brofenbrenner (1979). The Ecology of Human Development: Experiments by Nature and Design. Cambridge, MA: Harvard University Press.

Buehler, Ch. \& Welsh, D. P. (2009). A Process Model of Adolescent Triangulation into Parents' Marital Conflict: The Role of Emotional Reactivity. Journal of Family Psychology, 23(2), 167-180.

Buehler, Ch., Benson, M. J., \& Gerard, J. M. (2006). Interparental Hostility and Early Adolescent Problem Behavior: The Mediating Role of Specific Aspects of Parenting. Journal of Research on Adolescence, 16(2), 265-292.

Buehler, Ch., Krishnakumar, A., Stone, G., Anthony, Ch., Pemberton, S., \& Gerard, J. (1998). Interparental Conflict Styles and Youth Problem Behaviors: A Two-Sample Replication Study. Journal of Marriage and Family, 60, 119-132. 
Buehler, Ch., Anthony, CH., Krishnakumar, A., Stone, G., Gerard, J., \& Pemberton, S. (1997). Interparental Conflict and Youth Problem Behaviors: A Meta-Analysis. Journal of Child and Family Studies, 6(2), 233-247.

Cabrera, V. E., Guavera, I. P., \& Barrera, F. (2006). Relaciones maritales, relaciones paternas y su influencia en el ajuste psicológico de los hijos. Acta Colombiana de Psicología, 9(2), 115-126.

Calzada, E. J., Eyberg, S. M., Rich, B., \& Querido, J. G. (2004). Parenting Disruptive Preschoolers: Experiences of Mothers and Fathers. Journal of Abnormal Child Psychology, 32, 201-213.

Cantón, J., Cortés, M. R., \& Justicia, M. D. (2007). Conflictos entre los padres, Divorcio y Desarrollo de los Hijos. Madrid: Pirámide.

Ceballos, E. \& Rodrigo, M. J. (2000). Familia y Desarrollo Humano. España: Alianza Editorial.

Coiro, M. J. \& Emery, R. E. (1998). Do Marriage Problems Affect Fathering More than Mothering? A Quantitative and Qualitative Review. Clinical Child and Family Psychology, $1(1), 23-39$.

Cosgaya, L., Nolte, M., Martínez-Pampliega, A., Sanz, M., \& Iraurgi, I. (2008). Conflicto interparental, relaciones padres-hijos e impacto emocional en los hijos. Revista de Psicología Social, 23(1), 29-40.

Cox, J. M. \& Paley, B. (1997). Families as Systems. Annual Review of Psychology, 48, $243-$ 267.

Cummings, E. M., Schermerhorn, A. C., Davies, P. T., Goeke-Morey, M. C., \& Cummings, J. S. (2006). Interparental Discord and Child Adjustment: Prospective Investigations of Emotional Security as an Explanatory Mechanism. Child Development, 77(1), 132-152.

Cummings, E. M., Goeke-Morey, M. C., Papp, L. M., \& Dukewich, T. L. (2002). Children's Responses to Mother's and Father's Emotionality and Tactics in Marital Conflict in Home. Journal of Family Psychology, 16(4), 478-492.

Cummings, E. M. \& Davies, P. T. (2002). Effects of Marital Conflict on Children: Recent Advances and Emerging Themes in Process-oriented Research. Journal of Child Psychology and Psychiatry, 43(1), 31-63.

Cummings, E. M., \& Davies, P. T. (2010). Marital conflict and children: An emotional security perspective. New York: Guilford Press.

Cummings E. M. \& Wilson A. (1999). Contexts of Marital Conflict and Children's Emotional Security: Exploring the Distinction between Constructive and Destructive Conflict from the Children's Perspective. In Cox M. \& Brooks-Gunn J. (Eds.), Conflict and Closeness in Families: Causes and Consequences (pp. 105-129). Mahwah, NJ: Erlbaum.

Daniels, D. \& Plomin, R. (1985). Differential Experience of Siblings in the Same Family. Developmental Psychology, 21, 747-760.

Davies, P. T. \& Lindsay, L. L. (2004). Interparental Conflict and Adolescent Adjustment: Why Does Gender Moderate Early Adolescent Vulnerability? Journal of Family Psychology, 18(1), 160-170. 
Davies, P. T., Myers, R. L., Cummings, E. M., \& Heindel, S. (1999). Adult Conflict History and Children's Subsequent Responses to Conflict: An Experimental Test. Journal of Family Psychology, 13(4), 610-628.

Erath, S. A. \& Bierman, K. L. (2006). Aggressive Marital Conflict, Maternal Harsh Punishment, and Child Aggressive-Disruptive Behavior: Evidence for Direct and Mediated Relations. Journal of Family Psychology, 20(2), 217-226.

Erel, O. \& Burman, B. (1995). Interrelatedness of Marital Relations and Parent-Child Relations: A Meta-Analytic Review. Psychological Bulletin, 118(1), 108-132.

Flaquer, L. (1999). La Estrella Menguante del Padre. Barcelona: Editorial Ariel S.A.

Franck, K. L. \& Buehler, Ch. (2007). A Family Process Model of Marital Hostility, Parental Depressive Affect, and Early Adolescent Problem Behavior: The Roles of Triangulation and Parental Warmth. Journal of Family Psychology, 21(4), 614-625.

Fincham, F. D. (1994). Understanding the Association between Marital Conflict and Child Adjustment: Overview. Journal of Family Psychology, 8(2), 123-127.

Gerard, J. M., Krishnakumar, A., \& Buehler, Ch. (2006). Marital Conflict, Parent-Child Relations, and Youth Maladjustment: A Longitudinal Investigation of Spillover Effect. Journal of Family Issues, 27(7), 951-975.

Gerard, J. M., Buehler, Ch., Franck, K., \& Anderson, O. (2005). In the Eyes of Beholder: Cognitive Appraisal as Mediators of the Association between Interparental Conflict and Youth Maladjustment. Journal of Family Psychology, 19, 376-384.

Goeke-Morey, M. C., Cummings, E. M., \& Papp, L. M. (2007). Children and Marital Conflict Resolution: Implications for Emotional Security and Adjustment. Journal of Family Psychology, 21(4), 744-753.

Goeke-Morey, M. C., Cummings, E. M., Harold, G. T., \& Shelton, K. H. (2003). Categories and Continua of Destructive and Constructive Marital Conflict Tactics from the Perspective of U.S. and Welsh Children. Journal of Family Psychology, 17(3), 327-338.

Grych, J. H., Fincham, F. D., Jouriles, E. N., \& McDonald, R. (2000). Interparental Conflict and Child Adjustment: Testing the Mediational Role of Appraisal in the Cognitive-Contextual Framework. Child Development, 71(6), 1648-1661.

Grych, J. H., Seid, M., \& Fincham, F. D. (1992). Assessing Marital Conflict from the Child's Perspective: The Children's Perception of Interparental Conflict Scale. Child Development, 63(3), 558-572.

de Haan, A. D., Dekovic, M., \& Prinzie, P. (2011). Longitudinal Impact of Parental and Adolescent Personality on Parenting. Journal of Personality and Social Psychology.

OnlineFirst. doi: 10.1037/a0025254.

Harold, G. T., Shelton, K. H., Goeke-Morey, M. C., \& Cummings, E. M. (2004). Marital Conflict, Child Emotional Security about Family Relationships and Child Adjustment. Social Development, 13(3), 350-376.

Iraurgi, I., Marínez - Pampliega, A., Iriarte, L., \& Sanz, M. (2011). Modelo Cognitivo Contextual del Conflicto Interparental y la Adaptación de los Hijos. Anales de Psicología, 27(2), 562-573. 
Kaczynski, K. J., Lindahl, K. M., Laurenceau, J. P., \& Malik, N. M. (2006). Marital Conflict, Maternal and Paternal Parenting, and Child Adjustment: A Test of Mediation and Moderation. Journal of Family Psychology, 20(2), 199-208.

Kerig, P. K., Cowan, P. A., \& Cowan, C. P. (1993). Marital Quality and Gender Differences in Parent-Child Interactions. Developmental Psychology, 29(6), 931-939.

Krishnakumar, A., Buehler, Ch., \& Barber, B. K. (2003). Youth Perception of Interparental Conflict, Ineffective Parenting, and Youth Problem Behaviors in European-American and African-American Families. Journal of Social and Personal Relationships, 20(2), 239-260.

Krishnakumar, A. \& Buehler, Ch. (2000). Interparental Conflict and Parenting Behaviors: A Meta-Analytic Review. Family Relations, 49, 25-44.

Lemos, S., Fidalgo, A. M., Calvo, P., \& Ménendez, P. (1992). Validación de la Escala de Psicopatología Infanto - Juvenil YSR. Clínica y Salud, 3, 183-194.

Lindhal, K. M. \& Malik, N. M. (2011). Marital Conflict Typology and Children's Appraisal: The Moderating Role of Family Cohesion. Journal of Family Psychology, 25(2), 194-201.

Low, S. M. \& Stocker, C. (2005). Family Functioning and Children's Adjustment:

Associations among Parent's Depressed Mood, Marital Hostility, Parent-Child Hostility, and Children's Adjustment. Journal of Family Psychology, 19(3), 394-403.

Macek, P. (2003). Adolescence. Praha: Portál.

Margolin, G, Gordis, E. B., \& John, R. S. (2001). Coparenting: A Link between Marital Conflict and Parenting in Two-Parent Families. Journal of Family Psychology, 15(1), 3-21.

Matějček, Z. (2005). Výbor z díla. Praha: Nakladatelství Karolinum.

Minuchin, S. (2001). Familias y Terapia Familiar. Barcelona: Gedisa S.A.

Morgado, B. (2008). Experiencia del divorcio parental y ajuste psicológico infantil. Retrieved from http://fondosdigitales.us.es/tesis/tesis/742/experiencia-del-divorcio-parental-y-ajustepsicologico-infantil/

Muthén, L. K. \& Muthén, B. O. (2007). Mplus User's Guide (Sixth Edition). Los Angeles, CA: Muthén \& Muthén.

Nelson, J. A., O’Brien, M., Blankson, A. N., Calkins, S. D., \& Keane, S. P. (2009). Family Stress and Parental Responses to Children's Negative Emotions: Test of the Spillover, Crossover, and Compensatory Hypotheses. Journal of Family Psychology, 23(5), 671-679.

Nicolotti, L., El-Sheikh, M., \& Whitson, S. (2003). Children's Coping with Marital Conflict and Their Adjustment and Physical Health: Vulnerability and Protective Functions. Journal of Family Psychology, 17(3), 315-326.

Oliva, A. et al. (2011). El desarrollo positivo adolescente y los activos que lo promueven. Un estudio en centros docentes andaluces. Sevilla: Consejería de Salud de la Junta de Andalucía.

Ochoa, M.G., Ferrer, B.M., \& Pérez, S. M. (2006). Conflicto Marital, Apoyo Parental y Ajuste Escolar en Adolescentes. Anuario de Psicología 37(3), 249-261.

Peris, T. S., Goeke-Morey, M. C., Cummings, E. M., \& Emery, R. E. (2008). Marital Conflict and Support Seeking by Parents in Adolescence: Empirical Support for the Parentification Construct. Journal of Family Psychology 22(3), 633-642.

Redorta, J. (2007). Entender el Conflicto. Barcelona: Paidós. 
Rhoades, K. A., Leve, L. D., Neiderhiser, Harold, G. T., Shaw, D. S., \& Reiss, D. (2011). Longitudinal Pathways from Marital Hostility to Child Anger during Toddlerhood: Genetic Susceptibility and Indirect Effects via Harsh Parenting. Journal of Family Psychology, 25(2), 282-291.

Richmond, M. K. \& Stocker, C. M. (2003). Sibling's Differential Experiences of Marital Conflict and Differences in Psychological Adjustment. Journal of Family Psychology, 17(3), 339-350.

Richmond, M. K. \& Stocker, C. M. (2007). Changes in Children's Appraisal of Marital Discord from Childhood through Adolescence. Journal of Family Psychology, 21(3), 416425.

Saffod, S. M., Alloy, L. B., \& Pierracci, A. (2007). A Comparison of Two Measures of Parental Behavior. Journal of Child and Family Studies, 16, 375-384.

Samper, P., Cortés, M. T., Mestre, V., Nácher, M. Ch., \& Tur, A. M. (2006). Adaptación del Child's Report of Parental Behavior Inventory a Población Española. Psicothema 18(2), 263 271.

Sanz, M., Iraurgi, I, Martínez - Pampliega, A., \& Cosgaya, L. (2006). Conflicto Marital y Consumo de drogas en los Hijos. Addiciones, 18(1), 36-48.

Schermerhorn, A. C., Cummings, E. M., DeCarlo, C. A., \& Davies, P. T. (2007). Children's Influence in the Marital Relationship. Journal of Family Psychology, 21(2), 259-269.

Silverberg, S. B. \& Steinberg, L. (1990). Psychological Well-being of Parents with Early Adolescent Children. Developmental Psychology, 26(4), 658-666.

Sturge-Apple, M L., Davies, P. T., Winter, M. A., Cummings, E. M., \& Schermerhorn, A. (2006). Interparental Conflict and Children's School Adjustment: The Explanatory Role of Children's Internal Representations of Interparental and Parent-Child Relationships. Developmental Psychology, 44(6), 1678-1690.

Sturge-Apple, M. L., Davies, P. T., \& Cummings, E. M. (2006). Hostility and Withdrawal in Marital Conflict: Effects on Parental Emotional Unavailability and Inconsistent Discipline. Journal of Family Psychology, 20(2), 227-238.

Thurnher, M. (1976). Midlife Marriage: Sex Differences in Evaluation and Perspectives. International Journal of Aging and Human Development, 7, 129-135. 


\section{About authors}

Olga Vlachynská is a PhD student in Developmental Psychology at Masaryk University. Her research focuses on issues of psychological adaptation of children and adolescents in the context of parental conflicts a divorce situation.

Address: Faculty of Social Studies of Masaryk University, Joštova 10, 60200 Brno

Contact email: olga.trampotova@gmail.com

María del Mar González Rodríguez is a Full Professor of the University of Evolutionary Psychology and Education at the University of Seville since 1995. She is responsible for the development of research and intervention programs related to different unconventional family models: single-parent families in different circumstances (single mothers, divorced, widows) families of single mothers by choice, families of lesbian mothers or gay parents, etc.).

Ana Maria López Jímenez is a Full Professor of methodology of behavioral sciences at the University of Seville. At the department of experimental psychology she is an expert in data analysis in the context of family studies.

Lenka Lacinová received her PhD from the Masaryk University, Faculty of Social Studies in general psychology, currently she is Associate Professor at Masaryk University (developmental psychology). Her research interests are attachment, romantic relationships, interparental conflict, and child development.

Stanislav Ježek received his $\mathrm{PhD}$ in social psychology from the Masaryk University, Faculty of Social Studies. His current research interests focus on adolescent psychosocial development, autonomy formation during emerging adulthood, learning environments and research methods.

Vlachynská, O., del Mar González, M., López Jímenez, A., Lacinová, L., \& Ježek, S. (2017). E- psychologie, 11(4), 1-18. http://e-psycholog.eu/pdf/vlachynska_etal.pdf 